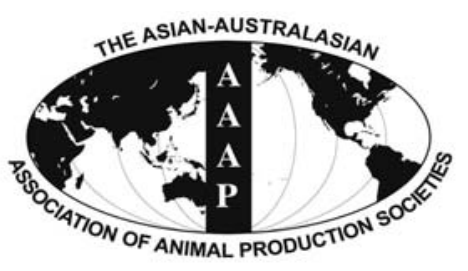

Asian-Aust. J. Anim. Sci.

Vol. 23, No. 1 : 13 - 16

January 2010

www.ajas.info

\title{
Effect of Exogenous Administration of Tamoxifen on Hormonal Profile and Sexual Maturity in Indian Native Kadaknath Fowl
}

\author{
A. Biswas*, J. Mohan and K. V. H. Sastry \\ Division of Physiology and Reproduction, Central Avian Research Institute, Izatnagar, Bareilly-243122, India
}

\begin{abstract}
The effect of exogenous administration of tamoxifen (TAM) on hormonal profile and sexual maturity in Indian native Kadaknath (KN) fowl was investigated. Day-old chicks from the same hatch were randomly divided into 15 groups with 20 chicks in each group ( 5 treatments $\times 3$ replicates). The chicks were placed in battery brooders with wire-mesh floors and reared under uniform husbandry conditions $\left(14 \mathrm{~h} \mathrm{light} / \mathrm{d}, 25-32^{\circ} \mathrm{C}\right)$ on a standard basal diet. At the age of two weeks (wk), birds from the control group $\left(\mathrm{T}_{1}\right)$ were injected with maize oil intramuscularly (I/M), whereas the other four experimental groups $T_{2}, T_{3}, T_{4}$ and $T_{5}$ were given tamoxifen (I/M) dissolved in maize oil at the rate of $0.5 \mathrm{mg}(0.5 \mathrm{TAM}), 1.0 \mathrm{mg}(1.0 \mathrm{TAM}), 2.5 \mathrm{mg}(2.5 \mathrm{TAM})$ and $5.0 \mathrm{mg}(5.0 \mathrm{TAM}) / \mathrm{kg}$ body weight, respectively, up to 30 wks on every alternate day. At every 6-wk interval, blood samples were collected from nine birds of each treatment group for estimation of estrogen and progesterone. The same birds were sacrificed for determination of the weight of ovary, oviduct, liver and adipose tissue. There was no significant difference in egg production traits except onset of lay and egg number. Low doses of TAM $\left(\mathrm{T}_{3}\right)$ advanced the onset of egg laying by 15 days over the control. Tamoxifen influenced the hormonal profile (estrogen and progesterone) in a dose dependent manner. However, higher doses of TAM suppressed ovary and oviductal growth. From this study, it may be concluded that lower doses of TAM enhanced sexual maturity while higher doses suppressed ovary and oviductal growth. (Key Words : Kadaknath, Egg Production, Steroid Hormone, Ovary, Oviduct)
\end{abstract}

\section{INTRODUCTION}

Tamoxifen (TAM) is an anti-oestrogen compound which inhibits the binding of estrogen to their receptors in brain and pituitary, thereby increasing gonadotropin secretion and gonadal activity (Jaccoby et al., 1992). Administration of TAM increased Luteinizing hormone (LH) secretion in juvenile male chicks (Wilson et al., 1983), increased testes weight and enhanced the spermatogenesis process in juvenile male broiler chicks (Rozenboim et al., 1986). Low doses $(1.0 \mathrm{mg} / \mathrm{kg}$ body weight) of TAM enhanced the growth of testes and comb, increased plasma testosterone level, advanced the age of semen production and sexual maturity in white leghorn (WL) male (Rozenboim et al., 1989). Similarly in young WL hens, low doses of TAM (0.1 $\mathrm{mg}$ and $1.0 \mathrm{mg} / \mathrm{kg}$ body weight) advanced ovarian and oviductal development and enhanced plasma estrogen and androgen resulting in early egg production (Jaccoby et al., 1992).

\footnotetext{
* Corresponding Author: Avishek Biswas. Tel: +91-1980-223042, Fax: +91-1982-252096, E-mail: drbiswas007@rediffmail.com Received August 8, 2008; Accepted January 19, 2009
}

Kadaknath $(\mathrm{KN})$ is an Indian native fowl which is known for poor egg production (120-140 eggs/laying cycle), slow growth, frequent broodiness, smaller body size (1.2$1.5 \mathrm{~kg}$ in adult), small egg size (40-42 g) and late sexual maturity. Eggs and meat production in birds is regulated by several complex interactions in which avian reproduction played an important role. Several studies have been done to understand this relationship in exotic breeds (Swain et al., 2000; Surai, 2002; Lin et al., 2005). However, such studies are to the best of our knowledge are absent in native fowls like Kadaknath.

Numbers of studies have been conducted to investigate the effects of tamoxifen on reproductive performances of WL chicken and turkeys but studies on KN fowls are lacking. Therefore, the present study was undertaken to examine the effects of exogenous administration of TAM on hormonal profile and sexual maturity in Indian native $\mathrm{KN}$ fowl.

\section{MATERIALS AND METHODS}

\section{Housing and rearing of birds}

Three hundred (300) healthy female KN chicks were 
Table 1. Effect of tamoxifen on egg production traits of Indian native kadaknath hen (Mean \pm SEM, $n=9$ )

\begin{tabular}{lcccccc}
\hline Group & $\begin{array}{c}\text { Age at lay } \\
\text { (Days) }\end{array}$ & Egg production & $\begin{array}{c}\text { Egg weight } \\
(\mathrm{g})\end{array}$ & $\begin{array}{c}\text { Albumin weight } \\
(\mathrm{g})\end{array}$ & $\begin{array}{c}\text { Yolk weight } \\
(\mathrm{g})\end{array}$ & $\begin{array}{c}\text { Shell thickness } \\
(\mathrm{mm})\end{array}$ \\
\hline $\mathrm{T}_{1}($ Control $)$ & 150 & $13.58 \pm 0.56^{\mathrm{b}}$ & $42.38 \pm 0.33$ & $22.12 \pm 0.38$ & $14.87 \pm 0.13$ & $0.32 \pm 0.06$ \\
$\mathrm{~T}_{2}(0.5 \mathrm{TAM})$ & 145 & $14.61 \pm 0.62^{\mathrm{b}}$ & $41.28 \pm 0.27$ & $21.08 \pm 0.42$ & $14.10 \pm 0.22$ & $0.31 \pm 0.07$ \\
$\mathrm{~T}_{3}(1.0 \mathrm{TAM})$ & 135 & $17.12 \pm 0.52^{\mathrm{c}}$ & $43.36 \pm 0.57$ & $23.77 \pm 0.54$ & $14.02 \pm 0.33$ & $0.30 \pm 0.05$ \\
$\mathrm{~T}_{4}(2.5 \mathrm{TAM})$ & 161 & $09.59 \pm 0.27^{\mathrm{a}}$ & $41.19 \pm 0.44$ & $20.13 \pm 0.62$ & $15.15 \pm 0.33$ & $0.30 \pm 0.06$ \\
$\mathrm{~T}_{5}(5.0 \mathrm{TAM})$ & Yet not lay & $0.00 \pm 0.00$ & $0.00 \pm 0.00$ & $0.00 \pm 0.00$ & $0.00 \pm 0.00$ & $0.00 \pm 0.00$ \\
\hline
\end{tabular}

Mean values bearing different letters within the column differed significantly $(\mathrm{p}<0.05)$.

randomly and equally divided into 15 groups (5 dietary treatments $\times 3$ replicates). The experiment was conducted by a randomized block design (Snedocor and Cochran, 1994). Chicks were placed in battery brooders with wire-mesh floors and reared under uniform husbandry conditions (14 h light/day, $25-32^{\circ} \mathrm{C}$ ) on a standard basal diet. The feeding, watering and collection of data during the course of the experiment was carried out by the same personnel. The experiment was conducted strictly in accordance with the guide lines of 'Institutional Animal Ethics Committee' (IAEC, CARI, Izatnagar, India).

\section{Administration of tamoxifen}

TAM was obtained from Sigma Chemicals Co., USA. The birds from the control group $\left(\mathrm{T}_{1}\right)$ were injected (1 $\mathrm{ml} / \mathrm{kg}$ body wt.) maize oil (vehicle), where as other four experimental groups $T_{2}, T_{3}, T_{4}$ and $T_{5}$ were given tamoxifen dissolved maize oil intramuscularly at the rate of $0.5 \mathrm{mg}$ (0.5 TAM), $1.0 \mathrm{mg}$ (1.0 TAM), $2.5 \mathrm{mg}$ (2.5 TAM) and 5.0 $\mathrm{mg}$ (5.0 TAM)/kg body weight respectively from the age of two wks on every alternate day. The experiment was terminated at the age of 30 weeks when all the control bird laid eggs.

\section{Egg production/bird/week}

Egg production from each treatment was recorded for a period of 3 wks $\left(28^{\text {th }}-30^{\text {th }}\right)$. Proper labeling on each egg was done in each and every day. Egg weight was taken by an analytical balance up to two decimals of a gram.

\section{Estimation of estrogen and progesterone}

The blood samples were collected at morning time from the jugular vein at the age of $6,12,18,24$ and 30 wks, using heparinised syringes after $24 \mathrm{~h}$ of TAM injection. All the samples were immediately centrifuged and plasma was collected for hormonal assay. Estrogen and progesterone were assayed in each sample by a micro plate reader (Spectromax-190, Molecular devices, USA) using commercial ELISA kits (Diagnostic System Laboratories Inc., Webster, TX, USA).

\section{Oviduct, ovary, liver and adipose tissue weight}

Every six wks interval three birds from each group were sacrificed by cervical dislocation to collect oviduct, ovary, liver and adipose tissue. The collected organs were weighed after removing the adhering tissues.

\section{Statistical analysis}

Data were analyzed using statistical software package developed at the Computer Centre of Central Avian Research Institute and followed standard procedures for ANOVA (Snedecor and Cochran, 1994) and Duncan's multiple range test (Duncan, 1955) by comparing means for significant differences.

\section{RESULTS AND DISCUSSION}

\section{Egg production traits}

Egg production, egg weight, albumin weight, yolk weight, and shell thickness of different TAM treated groups are presented in Table 1. Maximum $(\mathrm{p}<0.05)$ egg production was recorded in $\mathrm{T}_{3}$ (1.0 TAM) treated group followed by $\mathrm{T}_{2}$ (0.5 TAM), $\mathrm{T}_{1}$ (Control) and $\mathrm{T}_{4}$ (2.5 TAM) treated group. Among the different treatments, no significant ( $>>0.05$ ) differences were observed between the various egg production traits (except egg number) like egg weight, albumin weight, yolk weight, shell thickness. In case of onset of egg laying, significant differences were observed among the different TAM treated treatment. The birds treated with lower doses of TAM (1.0 TAM) started laying from 135 days while birds from 0.5 TAM, control and 2.5 TAM started laying at 145, 150 and 161 days respectively. However, the birds from 5.0 TAM treated group did not lay any eggs (Table 1).

Body weight (data not shown) was not affected in any of the TAM treated group throughout the experiment. This is in agreement with the works of Jaccoby et al. (1992). There was no significant difference in egg production traits among the different TAM treated group except egg number. However, low doses of TAM (0.5 TAM and 1.0 TAM) advanced the onset of egg laying and first egg in these groups was recorded at 145 and 135 days respectively. These results confirmed the earlier report in which the administration of anti-estrogen TAM to juvenile chicks resulted in precocious maturation in young WL hens (Jaccoby et al., 1992), Cockerels (Rozenboim et al., 1993), 
Table 2. Effect of tamoxifen on estrogen and progesterone level, weight of ovary, oviduct, liver and adipose tissue $\left(6^{\text {th }}\right.$ wk) in Indian native Kadaknath fowl (Mean \pm SEM, $n=9$ )

\begin{tabular}{lcccccc}
\hline Group & $\begin{array}{c}\text { Estrogen } \\
(\mathrm{pg} / \mathrm{ml})\end{array}$ & $\begin{array}{c}\text { Progesterone } \\
(\mathrm{ng} / \mathrm{ml})\end{array}$ & $\begin{array}{c}\text { Ovary weight } \\
(\mathrm{g})\end{array}$ & $\begin{array}{c}\text { Oviduct wt. } \\
(\mathrm{g})\end{array}$ & $\begin{array}{c}\text { Liver wt. } \\
(\mathrm{g})\end{array}$ & $\begin{array}{c}\text { Adipose tissue wt. } \\
(\mathrm{g})\end{array}$ \\
\hline $\mathrm{T}_{1}($ Control $)$ & $8.64 \pm 0.73^{\mathrm{a}}$ & $0.52 \pm 0.03^{\mathrm{a}}$ & $0.16 \pm 0.01^{\mathrm{bc}}$ & $0.05 \pm 0.01^{\mathrm{a}}$ & $08.96 \pm 0.49^{\mathrm{a}}$ & $2.18 \pm 0.11^{\mathrm{b}}$ \\
$\mathrm{T}_{2}(0.5 \mathrm{TAM})$ & $9.23 \pm 0.82^{\mathrm{a}}$ & $0.61 \pm 0.02^{\mathrm{b}}$ & $0.13 \pm 0.01^{\mathrm{a}}$ & $0.05 \pm 0.01^{\mathrm{a}}$ & $10.17 \pm 0.46^{\mathrm{b}}$ & $1.88 \pm 0.05^{\mathrm{ab}}$ \\
$\mathrm{T}_{3}(1.0 \mathrm{TAM})$ & $12.13 \pm 1.07^{\mathrm{b}}$ & $0.75 \pm 0.06^{\mathrm{c}}$ & $0.14 \pm 0.01^{\mathrm{ab}}$ & $0.07 \pm 0.01^{\mathrm{b}}$ & $09.08 \pm 0.28^{\mathrm{a}}$ & $2.65 \pm 0.09^{\mathrm{c}}$ \\
$\mathrm{T}_{4}(2.5 \mathrm{TAM})$ & $8.87 \pm 0.92^{\mathrm{a}}$ & $0.59 \pm 0.07^{\mathrm{ab}}$ & $0.13 \pm 0.01^{\mathrm{a}}$ & $0.06 \pm 0.01^{\mathrm{b}}$ & $09.25 \pm 0.50^{\mathrm{a}}$ & $2.43 \pm 0.15^{\mathrm{c}}$ \\
$\mathrm{T}_{5}(5.0 \mathrm{TAM})$ & $7.66 \pm 0.83^{\mathrm{a}}$ & $0.41 \pm 0.07^{\mathrm{a}}$ & $0.12 \pm 0.01^{\mathrm{a}}$ & $0.04 \pm 0.01^{\mathrm{a}}$ & $09.21 \pm 0.26^{\mathrm{a}}$ & $1.76 \pm 0.08^{\mathrm{a}}$ \\
\hline
\end{tabular}

Mean values bearing different letters within the column differed significantly $(\mathrm{p}<0.05)$.

Table 3. Effect of tamoxifen on estrogen and progesterone level, weight of ovary, oviduct, liver and adipose tissue (12 ${ }^{\text {th }}$ wk) in Indian native Kadaknath fowl (Mean \pm SEM, $\mathrm{n}=9$ )

\begin{tabular}{lcccccc}
\hline Group & $\begin{array}{c}\text { Estrogen } \\
(\mathrm{pg} / \mathrm{ml})\end{array}$ & $\begin{array}{c}\text { Progesterone } \\
(\mathrm{ng} / \mathrm{ml})\end{array}$ & $\begin{array}{c}\text { Ovary weight } \\
(\mathrm{g})\end{array}$ & $\begin{array}{c}\text { Oviduct wt. } \\
(\mathrm{g})\end{array}$ & $\begin{array}{c}\text { Liver wt. } \\
(\mathrm{g})\end{array}$ & $\begin{array}{c}\text { Adipose tissue wt. } \\
(\mathrm{g})\end{array}$ \\
\hline $\mathrm{T}_{1}($ Control $)$ & $31.28 \pm 3.22^{\mathrm{a}}$ & $0.60 \pm 0.76^{\mathrm{a}}$ & $0.55 \pm 0.03^{\mathrm{b}}$ & $0.64 \pm 0.02^{\mathrm{a}}$ & $27.25 \pm 1.70^{\mathrm{b}}$ & $9.68 \pm 0.28^{\mathrm{c}}$ \\
$\mathrm{T}_{2}(0.5 \mathrm{TAM})$ & $33.01 \pm 2.10^{\mathrm{a}}$ & $0.56 \pm 0.82^{\mathrm{a}}$ & $0.52 \pm 0.02^{\mathrm{b}}$ & $0.74 \pm 0.03^{\mathrm{b}}$ & $29.25 \pm 0.62^{\mathrm{b}}$ & $9.99 \pm 0.17^{\mathrm{c}}$ \\
$\mathrm{T}_{3}(1.0 \mathrm{TAM})$ & $36.17 \pm 2.26^{\mathrm{a}}$ & $0.95 \pm 0.73^{\mathrm{b}}$ & $0.68 \pm 0.02^{\mathrm{b}}$ & $0.90 \pm 0.04^{\mathrm{c}}$ & $28.75 \pm 0.72^{\mathrm{b}}$ & $8.88 \pm 0.22^{\mathrm{b}}$ \\
$\mathrm{T}_{4}(2.5 \mathrm{TAM})$ & $39.01 \pm 2.86^{\mathrm{b}}$ & $0.90 \pm 0.75^{\mathrm{b}}$ & $0.64 \pm 0.01^{\mathrm{b}}$ & $0.80 \pm 0.02^{\mathrm{b}}$ & $28.42 \pm 0.58^{\mathrm{b}}$ & $8.74 \pm 0.17^{\mathrm{b}}$ \\
$\mathrm{T}_{5}(5.0 \mathrm{TAM})$ & $39.12 \pm 2.14^{\mathrm{b}}$ & $0.85 \pm 0.91^{\mathrm{b}}$ & $0.40 \pm 0.01^{\mathrm{a}}$ & $0.57 \pm 0.03^{\mathrm{a}}$ & $25.67 \pm 0.33^{\mathrm{a}}$ & $6.63 \pm 0.23^{\mathrm{a}}$ \\
\hline
\end{tabular}

Mean values bearing different letters within the column differed significantly $(\mathrm{p}<0.05)$.

Table 4. Effect of tamoxifen on estrogen and progesterone level, weight of ovary, oviduct, liver and adipose tissue (18 ${ }^{\text {th }}$ wk) in Indian native Kadaknath fowl (Mean \pm SEM, $\mathrm{n}=9$ )

\begin{tabular}{lcccccc}
\hline Group & $\begin{array}{c}\text { Estrogen } \\
(\mathrm{pg} / \mathrm{ml})\end{array}$ & $\begin{array}{c}\text { Progesterone } \\
(\mathrm{ng} / \mathrm{ml})\end{array}$ & $\begin{array}{c}\text { Ovary weight } \\
(\mathrm{g})\end{array}$ & $\begin{array}{c}\text { Oviduct wt. } \\
(\mathrm{g})\end{array}$ & $\begin{array}{c}\text { Liver wt. } \\
(\mathrm{g})\end{array}$ & $\begin{array}{c}\text { Adipose tissue wt. } \\
(\mathrm{g})\end{array}$ \\
\hline $\mathrm{T}_{1}($ Control $)$ & $59.24 \pm 4.14^{\mathrm{a}}$ & $1.67 \pm 0.62^{\mathrm{a}}$ & $0.71 \pm 0.04^{\mathrm{a}}$ & $1.67 \pm 0.16^{\mathrm{ab}}$ & $30.58 \pm 0.44^{\mathrm{b}}$ & $25.06 \pm 0.13^{\mathrm{b}}$ \\
$\mathrm{T}_{2}(0.5 \mathrm{TAM})$ & $60.34 \pm 3.76^{\mathrm{a}}$ & $1.72 \pm 0.57^{\mathrm{a}}$ & $0.72 \pm 0.03^{\mathrm{a}}$ & $1.98 \pm 0.09^{\mathrm{bc}}$ & $31.25 \pm 0.66^{\mathrm{b}}$ & $24.08 \pm 0.90^{\mathrm{b}}$ \\
$\mathrm{T}_{3}(1.0 \mathrm{TAM})$ & $64.58 \pm 4.35^{\mathrm{a}}$ & $1.85 \pm 0.72^{\mathrm{ab}}$ & $0.94 \pm 0.02^{\mathrm{b}}$ & $2.40 \pm 0.11^{\mathrm{d}}$ & $31.42 \pm 0.44^{\mathrm{b}}$ & $24.56 \pm 0.78^{\mathrm{b}}$ \\
$\mathrm{T}_{4}(2.5 \mathrm{TAM})$ & $69.98 \pm 3.98^{\mathrm{b}}$ & $1.93 \pm 0.42^{\mathrm{b}}$ & $0.85 \pm 0.02^{\mathrm{b}}$ & $2.07 \pm 0.11^{\mathrm{c}}$ & $30.83 \pm 0.63^{\mathrm{b}}$ & $24.09 \pm 0.99^{\mathrm{b}}$ \\
$\mathrm{T}_{5}(5.0 \mathrm{TAM})$ & $70.32 \pm 3.57^{\mathrm{b}}$ & $2.92 \pm 0.39^{\mathrm{c}}$ & $0.79 \pm 0.01^{\mathrm{a}}$ & $1.59 \pm 0.11^{\mathrm{a}}$ & $24.42 \pm 0.65^{\mathrm{a}}$ & $20.84 \pm 0.73^{\mathrm{a}}$ \\
\hline
\end{tabular}

Mean values bearing different letters within the column differed significantly $(\mathrm{p}<0.05)$.

male turkeys and drakes (Rozenboim et al., 1993). To our knowledge, there have been no reports on the effects of exogenous administration of TAM on sexual maturity, egg production and hormonal profile of $\mathrm{KN}$ fowl.

\section{Estrogen and progesterone level and different organ weight}

The plasma concentrations of estrogen and progesterone were higher $(\mathrm{p}<0.05)$ at all the intervals in 1.0 TAM (T3) when compared to control $\left(\mathrm{T}_{1}\right)$ and 0.5 TAM $\left(\mathrm{T}_{2}\right)$. However, dose dependent increase in plasma estrogen and progesterone was noticed and highest level observed in birds administered in high doses of TAM. The weight of ovary and oviduct was higher in 1.0 TAM $\left(\mathrm{T}_{3}\right)$ than all other treatments at all the intervals. Liver weight increased in relation to the advancement of life in all the groups but the growth of liver was found significantly poor $(\mathrm{p}<0.05)$ at all intervals (except $6^{\text {th }}$ to $12^{\text {th }} \mathrm{wk}$ ) in the birds only received high doses of TAM (5.0 TAM). Similar pattern was observed in the adipose tissue (Tables 2, 3, 4, 5 and 6).

It is of interest to note that the progesterone level remained fairly low before 18 wk of age in all the treatments including control $\left(\mathrm{T}_{1}\right)$ (Tables 2, 3, 4, 5 and 6). The administration of TAM might have caused precocious maturation of gonadal pituitary axis in $\mathrm{KN}$ hen that enhanced the ovarian steroidogenesis, thus increased plasma estrogen and progesterone level in a dose related manner. This elevated concentration of estrogen and progesterone reflected in the weight of ovary, oviduct, liver and adipose tissues. Maximum increases in these parameters were recorded in pullets received 1.0 TAM $\left(\mathrm{T}_{3}\right)$ only (Tables 2, 3, 4, 5 and 6). Similar results were reported by several researchers (Hafez, 1995; Etches, 1990). In chicken estrogen stimulate the growth of oviduct, act on the liver to produce the specific yolk lipo-protein, increase deposition of body fat, cause the deposition of extra calcium in bones and finally help to bring about the typical female behaviour and regulation of LH release from pituitary through feedback mechanism. Besides, progesterone is more specific in its effect and caused oviductal growth and function. The highest dose (5.0 TAM) of TAM $\left(\mathrm{T}_{5}\right)$ appeared to inhibit the parameters investigated under this 
Table 5. Effect of tamoxifen on estrogen and progesterone level, weight of ovary, oviduct, liver and adipose tissue (24 ${ }^{\text {th }}$ wk) in Indian native Kadaknath fowl (Mean \pm SEM, $\mathrm{n}=9$ )

\begin{tabular}{lcccccc}
\hline Group & $\begin{array}{c}\text { Estrogen } \\
(\mathrm{pg} / \mathrm{ml})\end{array}$ & $\begin{array}{c}\text { Progesterone } \\
(\mathrm{ng} / \mathrm{ml})\end{array}$ & $\begin{array}{c}\text { Ovary weight } \\
(\mathrm{g})\end{array}$ & $\begin{array}{c}\text { Oviduct wt. } \\
(\mathrm{g})\end{array}$ & $\begin{array}{c}\text { Liver wt. } \\
(\mathrm{g})\end{array}$ & $\begin{array}{c}\text { Adipose tissue wt. } \\
(\mathrm{g})\end{array}$ \\
\hline $\mathrm{T}_{1}($ Control $)$ & $126.34 \pm 8.68^{\mathrm{a}}$ & $3.85 \pm 1.02^{\mathrm{a}}$ & $29.27 \pm 0.32^{\mathrm{b}}$ & $30.67 \pm 1.08^{\mathrm{b}}$ & $29.75 \pm 0.42^{\mathrm{b}}$ & $36.92 \pm 0.90^{\mathrm{b}}$ \\
$\mathrm{T}_{2}(0.5 \mathrm{TAM})$ & $129.01 \pm 6.07^{\mathrm{a}}$ & $4.01 \pm 0.91^{\mathrm{a}}$ & $28.50 \pm 0.55^{\mathrm{b}}$ & $32.30 \pm 1.22^{\mathrm{b}}$ & $29.71 \pm 0.33^{\mathrm{b}}$ & $37.14 \pm 1.52^{\mathrm{b}}$ \\
$\mathrm{T}_{3}(1.0 \mathrm{TAM})$ & $136.27 \pm 7.72^{\mathrm{b}}$ & $5.11 \pm 0.87^{\mathrm{b}}$ & $34.59 \pm 0.67^{\mathrm{c}}$ & $35.47 \pm 0.57^{\mathrm{c}}$ & $29.00 \pm 0.22^{\mathrm{b}}$ & $37.91 \pm 1.73^{\mathrm{b}}$ \\
$\mathrm{T}_{4}(2.5 \mathrm{TAM})$ & $138.00 \pm 6.79^{\mathrm{b}}$ & $5.25 \pm 0.78^{\mathrm{b}}$ & $30.68 \pm 0.47^{\mathrm{c}}$ & $30.92 \pm 0.59^{\mathrm{b}}$ & $29.42 \pm 0.30^{\mathrm{b}}$ & $38.29 \pm 1.46^{\mathrm{bc}}$ \\
$\mathrm{T}_{5}(5.0 \mathrm{TAM})$ & $142.07 \pm 5.10^{\mathrm{b}}$ & $6.18 \pm 0.80^{\mathrm{c}}$ & $21.82 \pm 0.98^{\mathrm{a}}$ & $21.66 \pm 0.75^{\mathrm{a}}$ & $23.33 \pm 0.25^{\mathrm{a}}$ & $34.71 \pm 0.77^{\mathrm{a}}$ \\
\hline
\end{tabular}

Mean values bearing different letters within the column differed significantly $(\mathrm{p}<0.05)$.

Table 6. Effect of tamoxifen on estrogen and progesterone level, weight of ovary, oviduct, liver and adipose tissue (30 ${ }^{\text {th }}$ wk) in Indian native Kadaknath fowl (Mean \pm SM, $\mathrm{n}=9$ )

\begin{tabular}{lcccccc}
\hline Group & $\begin{array}{c}\text { Estrogen } \\
(\mathrm{pg} / \mathrm{ml})\end{array}$ & $\begin{array}{c}\text { Progesterone } \\
(\mathrm{ng} / \mathrm{ml})\end{array}$ & $\begin{array}{c}\text { Ovary weight } \\
(\mathrm{g})\end{array}$ & $\begin{array}{c}\text { Oviduct wt. } \\
(\mathrm{g})\end{array}$ & $\begin{array}{c}\text { Liver wt. } \\
(\mathrm{g})\end{array}$ & $\begin{array}{c}\text { Adipose tissue wt. } \\
(\mathrm{g})\end{array}$ \\
\hline $\mathrm{T}_{1}($ Control $)$ & $105.11 \pm 5.01^{\mathrm{a}}$ & $3.97 \pm 0.97^{\mathrm{a}}$ & $36.93 \pm 0.35^{\mathrm{b}}$ & $40.64 \pm 0.66^{\mathrm{b}}$ & $29.33 \pm 0.25^{\mathrm{b}}$ & $40.69 \pm 1.33^{\mathrm{b}}$ \\
$\mathrm{T}_{2}(0.5 \mathrm{TAM})$ & $109.22 \pm 2.19^{\mathrm{a}}$ & $3.37 \pm 0.83^{\mathrm{a}}$ & $36.49 \pm 0.72^{\mathrm{b}}$ & $40.88 \pm 0.53^{\mathrm{b}}$ & $31.75 \pm 0.56^{\mathrm{b}}$ & $41.87 \pm 1.11^{\mathrm{b}}$ \\
$\mathrm{T}_{3}(1.0 \mathrm{TAM})$ & $131.38 \pm 3.27^{\mathrm{b}}$ & $5.28 \pm 0.96^{\mathrm{b}}$ & $42.83 \pm 1.06^{\mathrm{c}}$ & $40.92 \pm 1.24^{\mathrm{b}}$ & $30.17 \pm 0.55^{\mathrm{b}}$ & $42.61 \pm 0.91^{\mathrm{b}}$ \\
$\mathrm{T}_{4}(2.5 \mathrm{TAM})$ & $136.12 \pm 2.57^{\mathrm{b}}$ & $5.91 \pm 0.93^{\mathrm{b}}$ & $35.91 \pm 0.94^{\mathrm{b}}$ & $35.12 \pm 0.60^{\mathrm{b}}$ & $30.25 \pm 0.74^{\mathrm{b}}$ & $40.28 \pm 1.41^{\mathrm{b}}$ \\
$\mathrm{T}_{5}(5.0 \mathrm{TAM})$ & $135.21 \pm 3.13^{\mathrm{b}}$ & $6.27 \pm 0.87^{\mathrm{c}}$ & $30.08 \pm 1.34^{\mathrm{a}}$ & $29.78 \pm 0.95^{\mathrm{a}}$ & $22.08 \pm 0.30^{\mathrm{a}}$ & $35.32 \pm 1.40^{\mathrm{a}}$ \\
\hline
\end{tabular}

Mean values bearing different letters within the column differed significantly $(\mathrm{p}<0.05)$.

study even the elevated estrogen and progesterone concentration persist throughout the study period that depressed ovary and oviduct growth to a significantly $(p<0.05)$ lower level than that of control group $\left(T_{1}\right)$. Direct administration of estrogen in birds increased plasma lipid concentration, liver weight, and fat as well as abdominal adipose tissue (Lorenz, 1954; Aprahamian et al., 1979; Snapir et al., 1983). In this study, TAM is the indirect source that increased the estrogen concentration through steroidogenesis in turn enhanced the liver weight and fat deposition in KN fowl (Tables 2, 3, 4, 5 and 6).

It may be concluded that the lower doses of TAM (1.0 TAM and 0.5 TAM) advanced the sexual maturity by 15 and 05 days respectively as compared to control whereas; higher doses (2.5 TAM and 5.0 TAM) delayed sexual maturity and egg production. Higher doses of TAM suppressed the ovarian and oviductal growth when compared to lower doses of TAM and control.

\section{REFERENCES}

Aprahamian, S., M. J. Arslamin and J. K. Stoops. 1979. Effect of estrogen on fatty acid synthetase in the chicken oviduct and liver. Lipids. 14:1015-1020.

Duncan, B. 1955. Multiple range and multiple F tests. Biometrics. $11: 1-12$.

Etches, R. J. 1990. The ovulatory cycle of the hen. CRC Critical Rev. Poult. Biol. 2:293-318.

Hafez, E. S. E. 1995. Reproduction in farm animals. $6^{\text {th }}$ Edition, Len and Febiger, Philadelphia, USA.

Jaccoby, S., N. Snapir, E. Rozenboim, E. Arnon, R. Meidan and B. Robinzon. 1992. Tamoxifen advances puberty in the white leghorn. Br. Poult. Sci. 33:101-111.
Lin, Y. F., S. J. Chang, J. R. Yang, Y. P. Lee and A. L. Hsu. 2005. Effect of supplemental vitamin E during the mature period on the reproductive performance of Taiwan native chicken cockerels. Br. Poult. Sci. 46:366-372.

Lorenz, F. W. 1954. Effect of estrogen on domestic fowl and application in the poultry industry. Vitam. Horm. 12:235.

Rozenboim, I., O. Dgany, B. Robinzon, E. Arnon and I. Snapir. 1989. The effect of tamoxifen on the reproductive traits in white leghorn cockerels. Pharm. Biochem. Behav. 32:377-381.

Rozenboim, I., G. Gvaryahu, B. Robinzon, N. Sayag and I. Snapir. 1986. The induction of precocious development of reproductive function in cockerels by tamoxifen administration. Poult. Sci. 65:1980-1983.

Rozenboim, I., I. Snapir, E. Arnon, R. Argych, W. H. Bucken, P. J. Sharp, Y. Koch and B. Robinzon. 1993. Precocious puberty in tamoxifen treated cockerels; hypothalamic gonadotropin releasing hormone, plasma LH prolactin growth hormone and testosterone. Br. Poult. Sci. 34:533-542.

Snapir, N., B. Robinzon and B. Shalita. 1983. The involvement of gonads and gonadal steroids in the regulation of feed intake, body weight, and adiposity in the white leghorn cock. Pharm. Biochem. Behav. 19:617-624.

Snedecor, G. W. and W. G. Cochran. 1994. Statistical methods. $8^{\text {th }}$ Edition. Oxford and IBH Pub. Co., Kolkata, India.

Surai, P. F. 2002. Selenium on poultry nutrition, antioxidants properties, deficiency and toxicity. World's Poult. Sci. J. 58: 333-364.

Swain, B. K., T. S. Johari and S. Majumder. 2000. Effect of supplementation of vitamin $\mathrm{E}$ and selenium and their different combination on the performance and immune response of broilers. Br. Poult. Sci. 41:287-292.

Wilson, S. C., P. G. Knight and F. J. Cunnigham. 1983. Evidence for the involvement of central conversion of testosterone to estradiol-17 $\beta$ in the regulation of LH secretion in the cockerel. J. Endocrinol. 99:301-310. 